\title{
Water for Cranberry Culture in the Cranmoor Area of Central Wisconsin
}

GEOLOGICAL SURVEY WATER-SUPPLY PAPER 1999-I

Prepared in cooperation with University Extension-the University of $W$ isconsin Geological and Natural History Survey

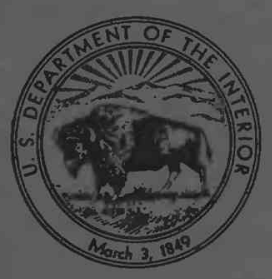




\section{Water for Cranberry Culture}

in the Cranmoor Area of Central Wisconsin

By LOUIS J. HAMILTON

CONTRIBUTIONS TO THE HYDROLOGY OF THE UNITED STATES

GEOLOGICAL SURVEY WATER-SUPPLY PAPER 1999-I

Prepared in cooperation with University Extension-the University of $W$ isconsin Geological and Natural History Survey

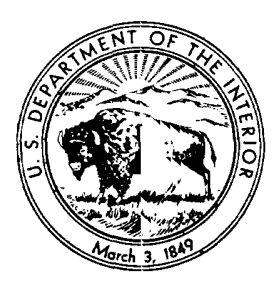




\section{UNITED STATES DEPARTMENT OF THE INTERIOP}

ROGERS C. B. MORTON, Secretary

\section{GEOLOGICAL SURVEY}

W. A. Radlinski, Acting Director

Library of Congress catalog-card No. 73-179320

For sale by the Superintendent of Documents, U.S. Government Printimg Office Washington, D. C. 20402

STOCK NUMBER 2401-1178 


\section{CONTENTS}

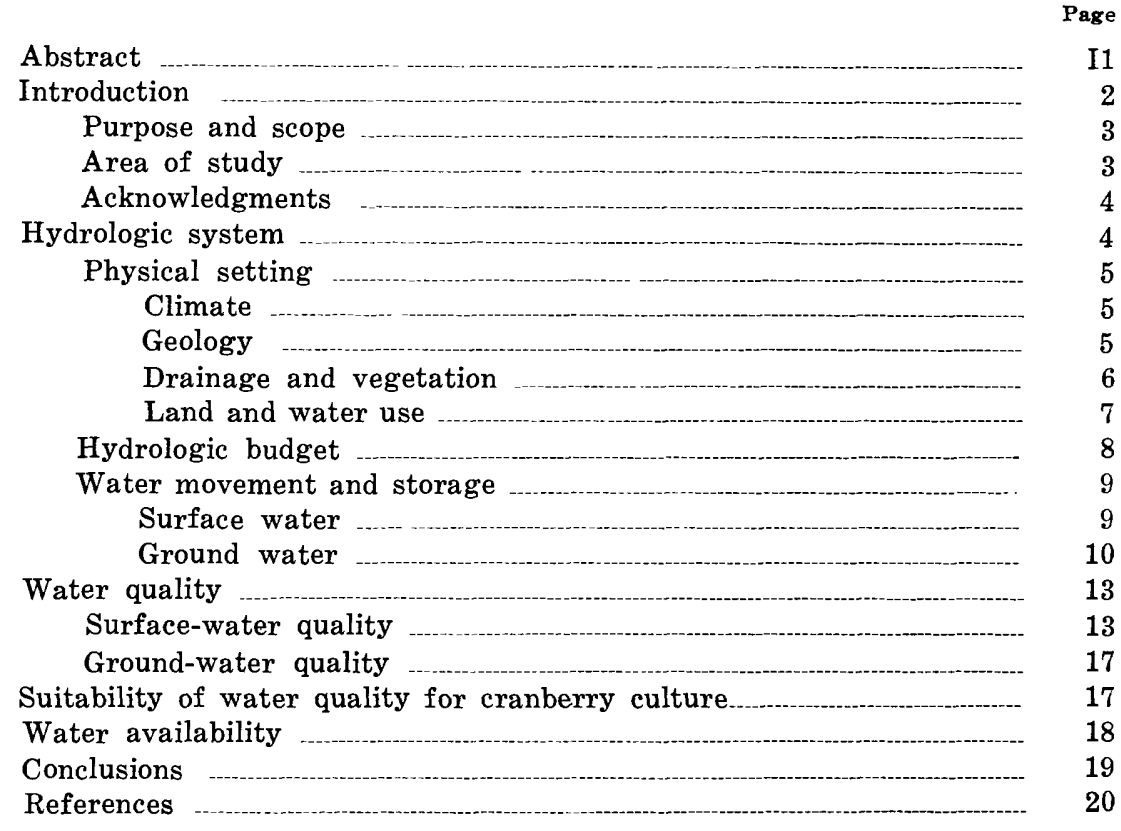

\section{ILLUSTRATIONS}

Plate 1. Hydrologic maps of the Cranmoor area, central

Wisconsin

Page

2. Map showing the thickness of unconsolidated deposits and potential well yields in the Cranmoor area, central Wisconsin

In rocket

Figure 1. Index map of Wisconsin showing location of the

Cranmoor area

2. Hydrographs of mean daily streamflow from Cranberry

Creek basin and related climatological data, 1966

\section{TABLES}

TABLE 1. Character of rock units in the wetlands

2. Tests of hydraulic properties of unconsolidated deposits

3. Quality of surface water in the Cranmoor area, Wisconsin

4. Quality of ground water in the Cranmoor area, Wisconsin 


\title{
CONTRIBUTIONS TO THE HYDROLOGY OF THE UNITED STATES
}

\section{WATER FOR GRANBERRY GULTUPE IN THE CRANMOOR AREA OF GENTRAL WISCONSIN}

\author{
By Louis J. HAMILTON
}

\begin{abstract}
The Cranmoor area of central Wisconsin is the principal cranberry producing area of the State. Cranberries are grown in only about 2.5 square miles of an 80-square-mile marsh and swamp in the Cranberry Creek basin. Cranberry growers have built reservoirs and ditches throughout 25 square miles of marsh for better management of the area's natural water supply. Additional water is diverted into the basin to supplement the cranberry neets.

In the 1966-67 hydrologic budget for Cranberry Creek basin, annual inputs were 27.8 inches of precipitation, 3.8 inches of surface-water diversion : into the basin, and 1.1 inches decrease in stored water. Annual outputs wer? 20.8 inches of evapotranspiration, 11.7 inches of runoff, and 0.2 inch of groundwater outflow. During the 1966-67 period, precipitation averaged about 3 inches per year below normal.

The water used for cranberry culture is almost exclusively surface vater. Efficient management of the basin's water supply, plus intermittent diversions of about 100 cubic feet per second from outside the basin, provide crarherry growers with a sufficient quantity of water. Although the quantity of surface water is adequate, the $\mathrm{pH}$ (generally 5.7-6.7) is slightly high for optimum use. Dissolved oxygen is slightly low, generally between 4 and 10 milligrams per liter. The water is soft; iron and manganese contents vary seascnally, being high in winter and summer and low in spring.

Additional supplies of surface water can be obtained by increasing diversions from outside the basin and by increasing reservoir capacity within the basin.

Ground water, although not presently used for cranberries, is available in the central, southern, and eastern parts of the basin, where the thickness of the saturated alluvium exceeds 50 feet. Well yields in these areas might be as much as $1,000 \mathrm{gpm}$ (gallons per minute). Additionally, well yields of as much as $1,000 \mathrm{gpm}$ may be expected from saturated alluvium southeast of Crarberry Creek basin. Where saturated alluvium is less than 50 feet thick, in the northern and western parts of the basin, well yields generally are less than $50 \mathrm{gpm}$. Ground water is also available from sandstone in the westerr part of the basin. Where the sandstone is thickest (about $60 \mathrm{ft}$.), well yields may be as much as $200 \mathrm{gpm}$.
\end{abstract}


The quality of ground water is similar to that of surface water. The $\mathrm{pH}$ of water from the shallow alluvium ranges between 6.0 and 6.6 ; the $\mathrm{pH}$ of water from the deep alluvium is about 7.0. Ground water is soft to moderately hard, 22 to 88 milligrams per liter, and contains excessive amounts of iron and manganese.

\section{INTRODUCTION}

Since about 1890 the wetland area near Cranmoor (fig. 1) has been the center of cranberry production in Wisconsin. In 1965,

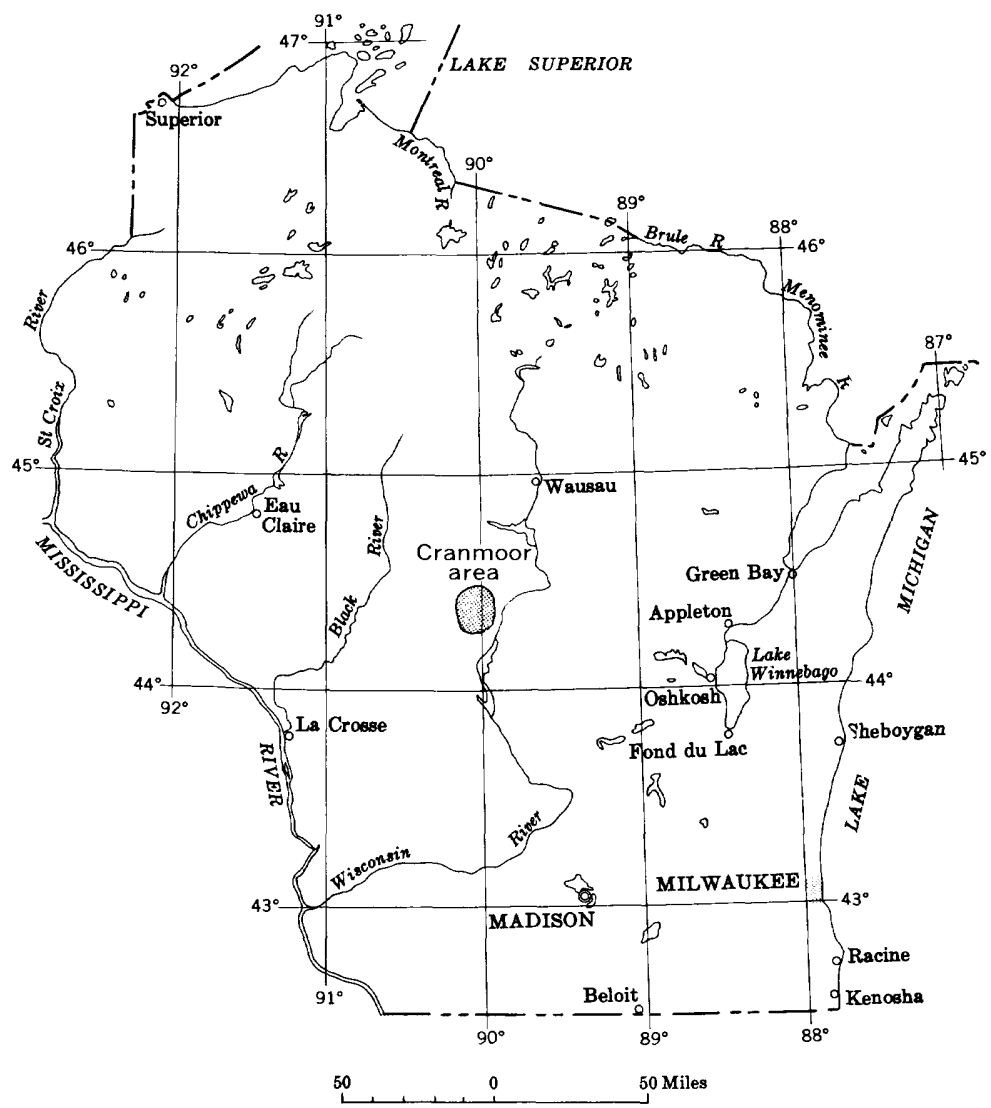

Figure 1.-Location of the Cranmoor area.

Wisconsin produced 44 million pounds of cranberries, about onethird of which was produced in this area (Dana and Klingbeil, 1966). This crop is the major contributor to the agricultural economy of the Cranmoor area.

Successful cranberry culture requires large quantities of water. 
Cranberry bogs are irrigated, flooded, or sprinkled 15 to 35 times a year to prevent damage from frost, to prevent winter desiccation of the vines, and to facilitate harvesting. Water levels in drainage ditches of bogs are regulated to maintain ground-water lovels near the root zones of the cranberry plants during the growing season. In recent years growers in the Cranmoor area have installed sprinkler systems to provide frost protection for the plants. The sprinklers, supplied by water from ditches, eliminate the need to flood for frost protection and reduce water use by about 75 percent (Malcolm N. Dana, oral commun., 1969).

Water for cranberry culture was exclusively from surface supplies at the time of this study (1965-69). Natural surface-vrater supply and storage capacities in Cranberry Creek basin are inadequate, making it necessary to construct drainage ditches and reservoirs and to divert water into the basin from adjacent areas. Most of the diverted water is pumped intermittently from the Wisconsin River at Wisconsin Rapids at a rate of $100 \mathrm{cfs}$ (cubic feet per second). Present and future power-generation demands for water in the Wisconsin River, as well as occasional waterquality concerns, limit consideration of additional diversions from the river.

\section{PURPOSE AND SCOPE}

The purposes of this investigation were to determine the a vailability and quality of water in the area, with emphasis on the possible use of ground water for cranberries, to determine the nature of the hydrologic system that operates in a wetland area, and to determine the effects of water management for crankerry culture.

The study included field determinations of the physical and hydrologic characteristics of aquifers, streams, and reservoirs; an appraisal of the hydrologic system; and a search for alternative methods of managing water for cranberry culture. Historical hydrologic data from the wetland area were scarce; no streamflow data were available, except for the lower Yellow River k'ssin for 1945-56, and little information was available on changes in ground-water levels.

\section{AREA OF STUDY}

The area includes approximately 80 square miles of marsh and drained swampland in the Cranberry Creek drainage basin. It is a few miles southwest of Wisconsin Rapids in Wood and Juneau Counties, in the northwestern part of Wisconsin's central sand plain. Cranberry Creek is 0 to 6 miles east of and tributary to the Yellow River, which flows into the Wisconsin River. The eastern 
and western boundaires of the study area are the ground-water divides of Cranberry Creek basin (pl. 1). Surface-water divides, which approximate the ground-water divides, are not used as boundaries because many ditches cross the divides. The northern boundary of the area is about a mile north of County Trunk Highway $Q$. The southern end of the study area is near the gaging station on Cranberry Creek, about 3 miles east of Finley.

\section{ACKNOWLEDGMENTS}

This study was planned and conducted by the U.S. Geological Survey, Water Resources Division, in cooperation with the University Extension-the University of Wisconsin Geological and Natural History Survey.

Data used for this report were collected with the permission and cooperation of the cranberry growers in the Cranmoor area. Mr. Samuel C. Castagna and the Wisconsin Rapids staff of the Division of Environmental Protection, Wisconsin Department of Natural Resources, are given special thanks for their cooperation in the collection of water-quality data. Surface-water-quality analyses were performed by the Wisconsin State Laboratory of Hygiene. Prof. Malcolm N. Dana, of the Department of Horticulture, University of Wisconsin, supplied informatior on methods and problems of cranberry culture. Acknowledgmert is made to Mr. Roger Bay and Mr. Don H. Boelter, of the U.S. Forest Service, and to Mr. P. G. Olcott, of the Wisconsin Geological and Natural History Survey, for their review of this report.

\section{HYDROLOGIC SYSTEM}

The hydrologic system in Cranberry Creek basin is influenced to a large degree by the water-management activities of cranberry growers. The quantity of water moving into and through the wetlands varies both seasonally and annually and is significantly altered by diversions for cranberry culture.

In winter the water-saturated soil in the undevelc ned wetlands is frozen to a depth of several feet, and the cranberry bogs are covered by 1 to 2 feet of ice. Ground-water discharge is small in the winter because of low ground-water levels and lack of recharge. Winter streamflow, which is almost entirely groundwater runoff, is also small.

Spring rain and snowmelt fill surface and grounc'-water reservoirs and cause large surface runoff from the wetlands. During spring and summer, runoff from the wetlands graduclly decreases, and evapotranspiration reaches its peak and depletes surfaceand ground-water reservoirs. 
In autumn, evapotranspiration decreases and streamflow remains low. However, heavy or prolonged rains in late summer or fall may produce flooding and surface runoff equal to that of spring. With the onset of winter, precipitation is again stored as ice and snow, and the annual cycle continues.

\section{PHYSICAL SETTING}

GLIMATE

The climate of the study area is continental, with long cold winters and short hot summers. The average annual air temperature is $6^{\circ} \mathrm{C}$ (Celsius) $\left(43^{\circ} \mathrm{F}\right)$, but a maximum temperature of $42^{\circ} \mathrm{C}\left(107^{\circ} \mathrm{F}\right)$ and a minimum temperature of $-24^{\circ} \mathrm{C}\left(-43^{\circ} \mathrm{F}\right)$ have been recorded at Wisconsin Rapids. Damaging frosts can occur during each month of the growing season. Climatologic data on the probability of freezes in Wisconsin were summarized by the Wisconsin Department of Agriculture (1961).

Total yearly precipitation averages 30.8 inches at the U.S. Weather Bureau station at Wisconsin Rapids but has ranged from 20.6 inches in 1894 to 46.8 inches in 1938. Precipitation is greatest in the summer, averaging about 3 inches per month, and least in late fall and winter, averaging less than 2 inches per month.

\section{GEOLOGY}

The area is underlain by crystalline rocks of Precambrian age and sandstone of Cambrian age and is mantled generally by unconsolidated Quaternary deposits of sand, gravel, and clay (table 1).

TABLE 1.-Character of rock units in the wetlands

\begin{tabular}{|c|c|c|c|}
\hline System & Rock unit & $\underset{\text { (feet) }}{\text { Thickness }}$ & Character \\
\hline Quaternary & $\begin{array}{l}\text { Loess and dune sand } \\
\text { Peat } \\
\text { Alluvium, glacial outwash, and } \\
\text { lake deposits, undifferentiated. }\end{array}$ & $\begin{array}{l}0-5 \\
0-3 \\
0-110\end{array}$ & $\begin{array}{l}\text { Coarse to very fine sand. } \\
\text { Sandy and woody sedge peat. } \\
\text { Coarse to fine sand, sandy } \\
\text { calcareous clay, and gravel. }\end{array}$ \\
\hline Cambrian & Sandstone & $0-60$ & $\begin{array}{l}\text { Coarse to fine-grained sandstor e, } \\
\text { silty, very friable. }\end{array}$ \\
\hline Precambrian & Residual clay & $\begin{array}{c}\text { 0-2 } \\
\text { Unknown }\end{array}$ & $\begin{array}{l}\text { Reddish-brown, bluish-gray, or } \\
\text { greenish-gray clay or clayey } \\
\text { gravel; fills cracks in crystalline } \\
\text { rocks. } \\
\text { Quartzite, gneiss, and schist; donse; } \\
\text { deeply weathered in upper and } \\
\text { fractured zones. }\end{array}$ \\
\hline
\end{tabular}

Crystalline rocks underlying the area are poorly permeable. The surface of the crystalline rocks resembles an irregular broad plain that slopes gradually about 10 feet per mile from north to 
south. A thin layer of preglacial reddish-brown, greenish-gray, or bluish-gray clay overlies much of the crystalline rock.

Sandstone, consisting of course to fine grains of quartz partially cemented by silica and iron oxide, overlies the crystalline rocks in the northwestern, southwestern, and eastern parts of the area. The sandstone is thin-generally less than 60 feet thick -but it increases in thickness south of the basin.

Sandstone, which once covered all the area, has been removed by erosion in the central and northeastern parts. A tributary of the preglacial Wisconsin River drained west to east across this area and developed a channel in the bedrock (shown by thick unconsolidated deposits just south of Cranmoor on pl. 2).

Unconsolidated sediments originated as outwash transported into the area by melt-water streams draining from the east and as clay, silt, and sand deposited in local lakes and in a northern extension of glacial Lake Wisconsin. The preglacial valley was filled with sand, silt, and some clay.

Alluvium consists predominantly of sand and some silt, clay, and gravel. Course to fine gray sand with some silt and clay is characteristic of samples collected from test holes in the area. Alluvium in the southern part of the area thickens from 40 feet in the west to 60 feet in the east (pl. 2). Shallow se.nd, 10 to 20 feet thick, overlies clay and deep sand and gravel. The thickest deposits of sand, which are more than 60 feet thick, occur in the buried bedrock valley and its tributaries. Sand is less than 20 feet thick in the north and along the western side of the area.

Alluvium in the buried valley decreases from east to west in thickness and in grain size. Thick lake deposits of silty sand that contain clay lenses occur at 20- to 70-foot depths in the west (test holes $\mathrm{N}, \mathrm{O}$, and Q, pl. 2). More than 100 feet of well-sorted sand occurs in the east.

\section{DRAINAGE AND VEGETATION}

Most of the Cranmoor area is considered a wetland because, historically, the land has been covered by shallow water or subject to intermittent flooding. Natural surface drainage is poor. However, the swamp area in the south has been partially drained by ditches, and the marsh area in the north has been dammed for reservoirs or locally drained for cranberry bogs.

The wetlands are centrally located in the flat Cranberry Creek basin. They slope southward about 5 feet per mile, and surface drainage from the marsh is restricted by low sand dunes on the south. 
Marsh, wetlands without trees, covers approximately 25 square miles in the northwestern and central parts of the area. Much of the marsh is perennially flooded by water stored for use in cranberry culture. Native vegetation is mostly sedge and cattail. Cranberry bogs, totaling about 2.5 square miles, are scattered thrcughout the marsh. The bogs consist of level beds of cranberry vines separated by a network of shallow ditches used for flooding and irrigating. Marshland and cranberry bogs are shown on the base maps of pl. 1.

Swamp, wetlands with trees, covers approximately 55 scuare miles in the southern and eastern parts of the area. The swamp floods during periods of heavy precipitation and rapid snowmelt and is drained by north-south ditches spaced about 1 mile apart. Native vegetation is mostly jack pine and scrub oak. About 10 square miles of swamp have been cleared for grazing and farming.

\section{I.AND AND WATER USE}

Commercial cranberry culture has significantly influenced the hydrologic system operating in the wetlands, owing to construction of reservoirs and check dams on ditches in the crant?rry bogs since the 1890's.

Cranberry bogs are developed on level, drained marsh. Cranberry vines are cultivated in 2- to 4-acre plots about 150 feet wide and 500 to 1,000 feet long separated by a network of ditches used for drainage, irrigation, and periodic flooding. Water, stored in reservoirs and controlled by dams and ditches within the marshes, is used for flooding and irrigating. Cranberry bogs are flooded with 12 to 18 inches of water in the fall to facilitate harvesting and in the winter to protect the perennial crank vines from severe cold and desiccation.

Before 1965 cranberry bogs were flooded with 2 to 3 inches of water at each frost threat. During periods of extreme cold the depth of water was increased to as much as 18 inches. Such f'ooding required several hours and large quantities of water to fill the ditches and cover the bogs. Water was wasted when frost did not occur. The average annual depth of water applied to 2.5 square miles of bogs for all uses was about 10 feet.

Since 1965 most of the growers have installed sprinkler systems, which are supplied with water from ditches, for irrigation and frost protection. Water from the sprinklers is applied frequently for irrigation and 15 to 30 times a year for frost pratection; 0.1 to 0.2 inch of water is applied during each sprinkling. Because of the sprinkling, the average annual depth of wrater 
applied to 2.5 square miles of bogs has decreased from 10 feet in 1965 to about 6 feet in 1968.

Most of the southern part of the wetlands was drained for farming in the early 1900's. During the period 1906-16 the channel of Cranberry Creek was dredged and straightened, and about 90 miles of connecting ditches, 5 to 10 feet deep and 4 to 40 feet wide, were constructed to provide drainage (Jones and others, 1923 , p. 114). As a result of this ditching, ground-water levels declined as much as 10 feet near the ditches and less between the ditches. Dryland farming in the drained wetlend was unprofitable due to drought, low soil fertility, and wind erosion.

In the period 1934-36, check dams were constructed in the main ditches at 1.5- to 2-mile intervals to raise water levels and increase soil moisture. Following this period, ground-water levels recovered to within 1 or 2 feet of preconstruction levels.

\section{HYDROLOGIC BUDGET}

A generalized hydrologic budget is a balance of the water entering and leaving the study area, including changes in surface- and ground-water storage. Hydrologic data collected during calendar years 1966 and 1967 were used in an average annucl budget for that part of Cranberry Creek drainage basin north $c$ the gaging station on County Trunk Highway F, 3 miles east of Finley. The drainage area includes the study area (approximate'y $80 \mathrm{sq} \mathrm{mi}$ ) and 16 square miles directly north of the study-area boundary (County Trunk Highway Q). The total volume of water in each budget item is expressed as an equivalent depth of water, in inches, spread evenly on the basin.

Water entering the basin over the 2-year period included annual precipitation averaging 27.8 inches, which was 3 inches below normal, and diversions into the basin averaging 3.8 inches, which was about 1.3 inches above normal. About 0.8 inch of the water diverted into the basin was from Hemlock Creek, and the other 3.0 inches was from the Wisconsin River. Ground-water inflow to the basin was negligible.

Water leaving the basin, by surface- and ground-water outflow and evapotranspiration, averaged 31.6 inches annually. Surface-water outflow averaged 11.7 inches. Apprcximately 80 percent of this water was discharged through Cranberry Creek near Finley, at the southern tip of the basin; the remaining 20 percent was discharged via a ditch to Hemlock Creek near Babcock (SE1/4 sec. 12, T. 21 N., R. 3 E.). Ground-water outflow across 
southern and western drainage divides was estimated to 1 ? 0.2 inch.

Evapotranspiration, 20.8 inches of water per year, was calculated by balancing the other budget items. It was several inches below estimates of potential evapotranspiration, mainly because precipitation was below normal and soil-moisture deficiencies reduced transpiration in the swamp.

Changes in surface- and ground-water storage during the study period were determined from changes in reservoir stage and ground-water levels. Storage decreased an average of 1.1 inches per year during the study period; most of the change was in ground-water storage. The decrease in storage was calculated as part of the annual input.

\section{WATER MOVEMENT AND STORAGE}

\section{SURFACE WATER}

Surface water enters the marsh as natural drainage from the northern uplands via Elm Creek and an unnamed stream 2 miles east of Elm Creek, and as diversions, which are made for supplemental filling of reservoirs, from the Wisconsin River and Hemlock Creek (pl. 1A). Natural drainage from the uplands decreases rapidly after rains and snowmelt because of small ground-water storage capacity and a steep surface slope (20 to 50 feet per mile). As an example of this rapid runoff from the 16 square miles of uplands, total inflow at four sites declined from 117 cfs (cubic feet per second) on March 3, 1966, to nearly zero on May 26, 1966.

Surface-water storage, mostly in the northern part of the wetlands, ranges from approximately 46,000 acre-feet during wet periods to 11,000 acre-feet during dry periods. The averag? surface-water storage during the study period was approxinately 23,000 acre-feet. An annual average of 20,000 acre-feet of water was diverted from outside the basin to 25 square miles of marsh used as reservoirs.

Wisconsin River water is diverted to the area via Cranberry Canal. The water is pumped into the canal at Wisconsin Fiapids at about $100 \mathrm{cfs}$ for about 80 days each year. Most water is diverted during August, September, and October for storage in reservoirs and later release for irrigation, harvesting, and frost protection. In addition to this regular diversion, flood water from the Wisconsin River and tributary streams entering the canal averaged about $90 \mathrm{cfs}$ from June 12 to $17,1967$. 
Water is diverted from Hemlock Creek in early spring and during brief flood periods in summer and fall to replenish water used in flooding bogs and water lost to evapotranspiration. Flood diversion from Hemlock Creek flows through ditches by gravity and enters the study area in the NE1/4, sec. 4 and the NW1/4, sec. 20 , T. 22 N., R. 4 E. Inflow near these sites is estimated to have averaged $23 \mathrm{cfs}$ for about 3 months each year during 1966-67. Surface water moves from north to south, leaving the study area via Cranberry Creek and ditches to Hemlock Creek ir the SW1/4 sec. 29 , T. 22 N., R. 4 E., and in the SE1/4 sec. 12, T. 21 N., R. 3 E. (pl. 1A).

The diversion of water into Cranberry Creek basin from the Wisconsin River and Hemlock Creek increases the annual runoff from the basin. Diversions do not contribute significantly to low flow during summer months because much of the weter is held in reservoirs for fall releases to the bogs. During the filling of reservoirs the flow of Cranberry Creek below the reservoirs is decreased. Subsequent bog drainage temporarily increases the flow of the creek and the bog drains.

About 80 percent of the surface water leaving the area, an average of $70 \mathrm{cfs}$ for 1966-67, was discharged through Cranberry Creek. Most of the remainder, an average of $14 \mathrm{cfs}$, was discharged through the ditch to Hemlock Creek (fig. 2). Discharge hydrographs for these streams for 1966 are shown in figure 2.

As ground- and surface-water storage is depleted by drainage, evapotranspiration, and irrigation, the flow from the wetlands decreases. In July 1966 the average flow of Cranb?rry Creek near Finley was 10 percent of the average flow in April. The lowest mean daily discharge recorded at this site during the 1966-67 period was 13 cfs in September 1967.

\section{GROUND WATER}

Ground water in alluvium generally moves slowly and, like surafce water, moves from north to south. Average ground-water storage in the study area is approximately 340,000 acre-feet. Ground-water storage varies only about 10 percent from the average because drainage ditches are shallow and existing groundwater pumpage is negligible. Locally, shallow ground water moves toward drainage ditches. The general direction of shallow groundwater movement, which is generally perpendicular to the waterlevel contours, is illustrated by the altitude and configuration of the water table ( $\mathrm{pl} .1 B$ ). 


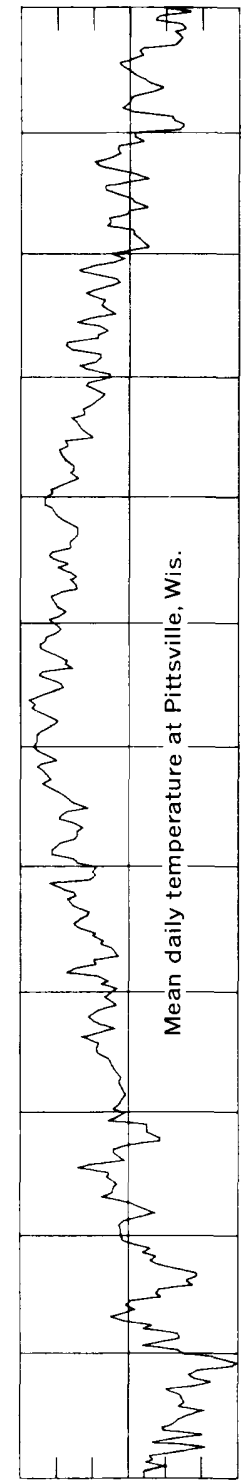

임 잉ㅇㅇ 유

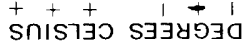

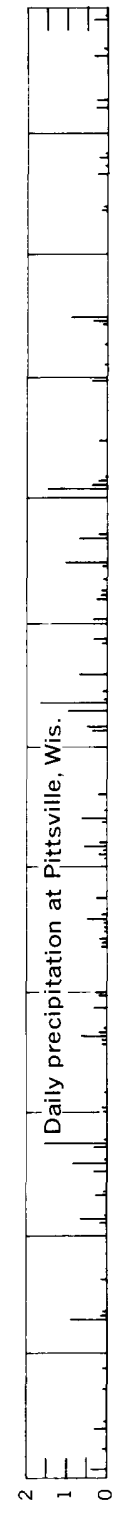

SAHONI

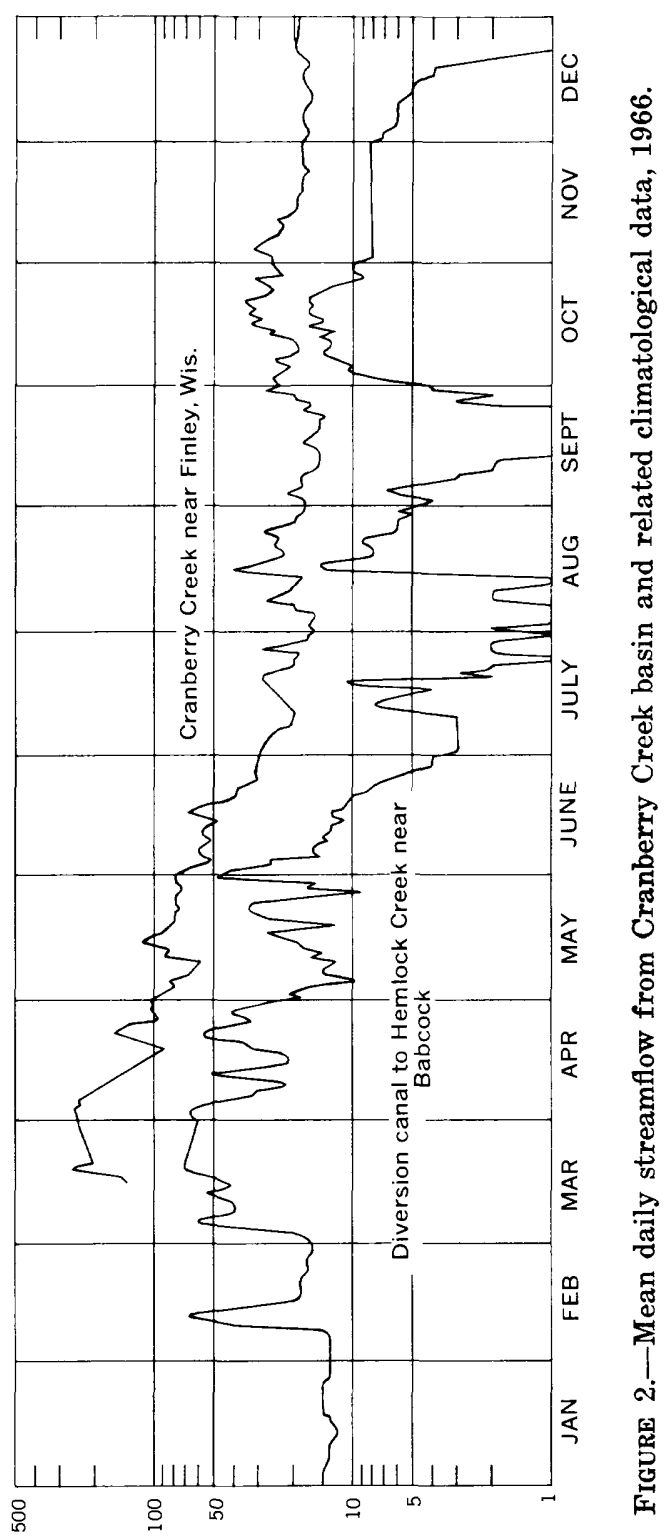

anOOتS y 
The rate of water movement in the northern part of the wetlands is rapid because the slope of the water table averages about 10 feet per mile. (See area north of the 990-ft contour on pl. 1B.) In this area of thin alluvium, the bedrock slope of 10 feet per mile controls the slope of the water table.

The rate of movement is less rapid in the area between the 990and 985 -foot contours and between the 980 - and 975-font contours (pl. $1 B$ ), where the slope is 5 feet per mile. This decrease in water-level slope reflects the increased transmissivity of sediments in the buried bedrock valley and the ponding of surface water in reservoirs.

Much of the ground water moving into the southern part of the wetlands discharges into ditches tributary to Cranb?rry Creek. However, not all the ground water moving through deep sand underlying clay discharges to the streams. About 1 mil ion gallons per day leaves the southern end of the basin as underflow.

The rate of ground-water movement depends on the hydraulic conductivity and the hydraulic gradient of the aquifer. Hydraulic conductivity (measured in gallons per day per square foot) of a material is equal to the discharge through the material divided by the area through which the flow is occurring and by the hydraulic gradient. The capacity of an aquifer to transmit water is its transmissivity (measured in gallons per day per foot), which is the saturated thickness of the aquifer times the hydraulic conductivity. Hydraulic properties of unconsolidater deposits, determined from aquifer tests, are shown in table 2.

At one site, in the SE1/4,SW1/4 sec. 34, T. 22 N., R. 4 E., hydraulic characteristics were estimated from auger samr'es of permeable sand and gravel about 90 feet thick. The aversge hydraulic conductivity at this site probably exceeds 1,000 gand (gallons per day) per square foot, and the transmissivity of the aquifer probably is at least 100,000 gpd per foot. The potential yield for

TABLE 2.-Tests of hydraulic properties

[Test location number gives, in order, county

\begin{tabular}{|c|c|c|c|c|c|}
\hline Location of test & Type of test & Date & $\begin{array}{l}\text { Length } \\
\text { of test } \\
\text { (days) }\end{array}$ & $\begin{array}{l}\text { Well } \\
\text { depth } \\
\text { (feet) }\end{array}$ & $\underset{\text { pumping }}{\text { Rate of }}$ \\
\hline $\begin{array}{l}\text { Wd-22/5/22 } \\
\text { Wd-22/5/34 } \\
\text { Wd-21/4/30 }\end{array}$ & $\begin{array}{l}\text { Pumping }{ }^{1} \\
\text { W }^{- \text {doter-level }^{2}} \\
\text { recession. }\end{array}$ & $\begin{array}{l}\text { Jan. 8-10, } 1961 \\
\text { Sept. 17-20, } 1956 \\
\text { Apr. 22-June 12, } \\
1966 .\end{array}$ & $\begin{array}{r}2 \\
3 \\
50\end{array}$ & $\begin{array}{r}55 \\
20 \\
6\end{array}$ & $\begin{array}{l}165 \\
115\end{array}$ \\
\hline
\end{tabular}

${ }^{1}$ Data from Becher-Hoppe Engineers, Inc., Schofield, Wis.

2 Data from Ranney Method Water Supplies, Inc., Columbus, Ohio. 
a well in this thick deposit of clean sand and gravel, which may extend into other areas, may be as much as $1,000 \mathrm{gpm}$ (gallons per minute).

Hydraulic characteristics of unconsolidated deposits ars not uniform throughout the area because the deposits differ in lithology and thickness. Coarse to medium sand predominates in the preglacial valleys in the eastern part of the area, and fine clayey sand predominates in the western part of the major preglacial valley. The deposits generally thicken to the east, and the transmissivity increases. The highest hydraulic conductivity and transmissivity (table 2) determined from aquifer tests were east of the Cranmoor basin near Port Edwards (sec. 34, T. 22 N., R. 5 E.), where unconsolidated deposits are sand and gravel like those in the eastern part of the basin. The wells in the Nekoosa area induce recharge from nearby surface water, and yields ar? extremely high with only small drawdowns.

Hydraulic characteristics of the shallow sand in the ee atern and southern parts of the basin may be similar to the charrcteristics estimated from the water-level-recession analysis for sec. 30, T. 21 N., R. 4 E. (table 2). At this site, saturated shallow sand is only 10 feet thick and is underlain by poorly permeable clayey sand. Deeper sand underlies this site, and a pumping test on a well developed through the entire thickness of unconsolidated deposits might give much higher values for hydraulic char cteristics than are shown in table 2.

\section{WATER QUALITY \\ SURFACE-WATER QUALITY}

Surface-water quality is fairly uniform throughout the study area and is typical of water in a wetland environment. The water is soft, has low dissolved-solids content, has high iron and manganese contents, and has a $\mathrm{pH}$ generally between 5.7 and 6.7. High

of unconsolidated deposits

(Wood, Wd), township, range, and section]

\begin{tabular}{|c|c|c|c|c|}
\hline \multicolumn{2}{|l|}{ Aquifer properties } & \multicolumn{3}{|c|}{ Hydraulic properties } \\
\hline Lithology & $\underset{\text { (feet) }}{\text { Thickness }}$ & $\begin{array}{l}\text { Average hydraulic } \\
\text { conductivity } \\
\text { (gpd per sq } \mathrm{ft} \text { ) }\end{array}$ & $\begin{array}{c}\text { Transmissivity } \\
\text { (gpd per ft) }\end{array}$ & $\begin{array}{l}\text { Sirrage } \\
\text { coefficient }\end{array}$ \\
\hline $\begin{array}{l}\text { Gravel, sand, silt, and clay } \\
\text { Sand and gravel. } \\
\text { Sand, coarse to medium }\end{array}$ & $\begin{array}{l}20 \\
17 \\
10\end{array}$ & $\begin{array}{l}1,000 \\
2,000 \\
1,500\end{array}$ & $\begin{array}{l}21,000 \\
33,200 \\
15,000\end{array}$ & 0.05 \\
\hline
\end{tabular}




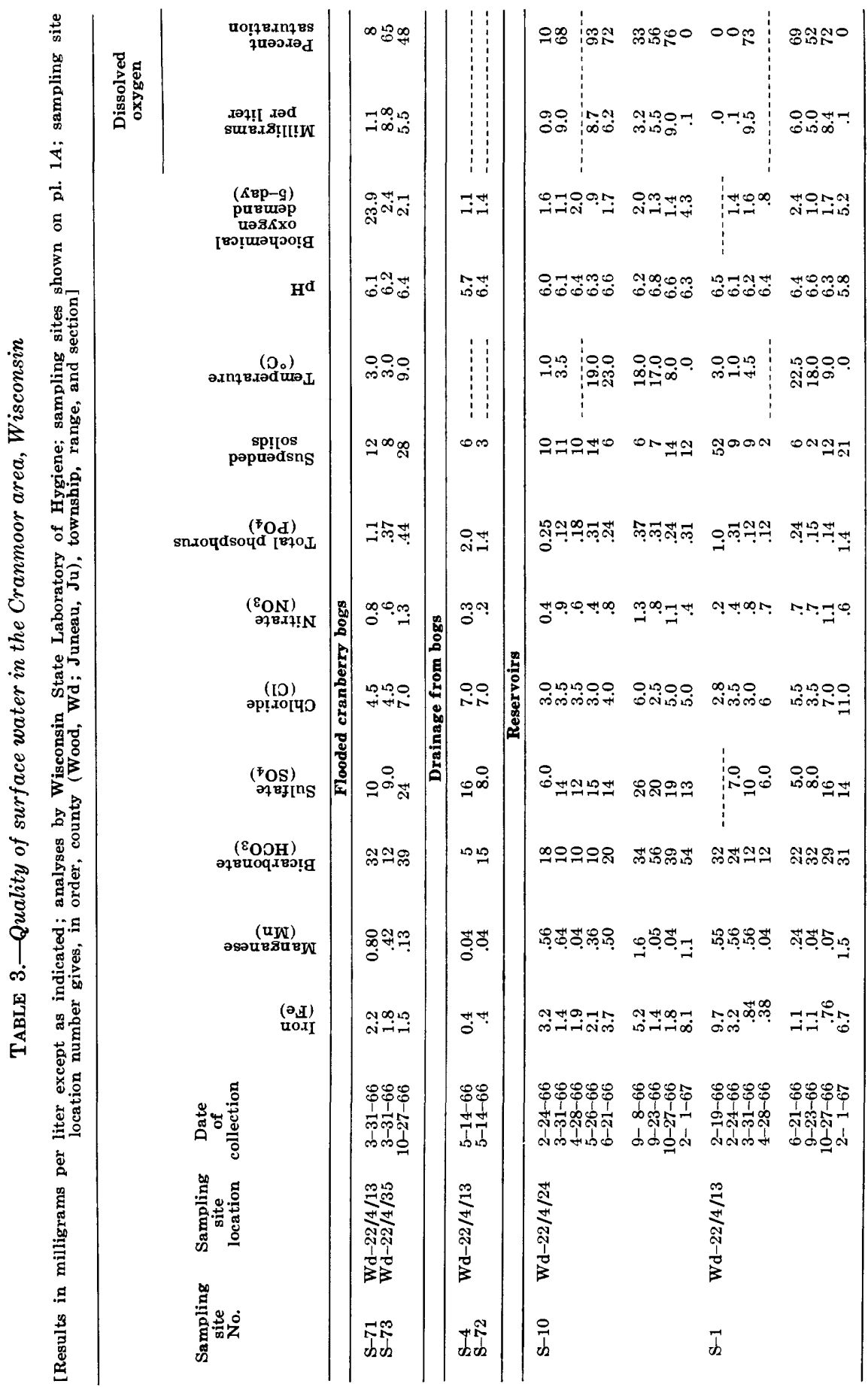




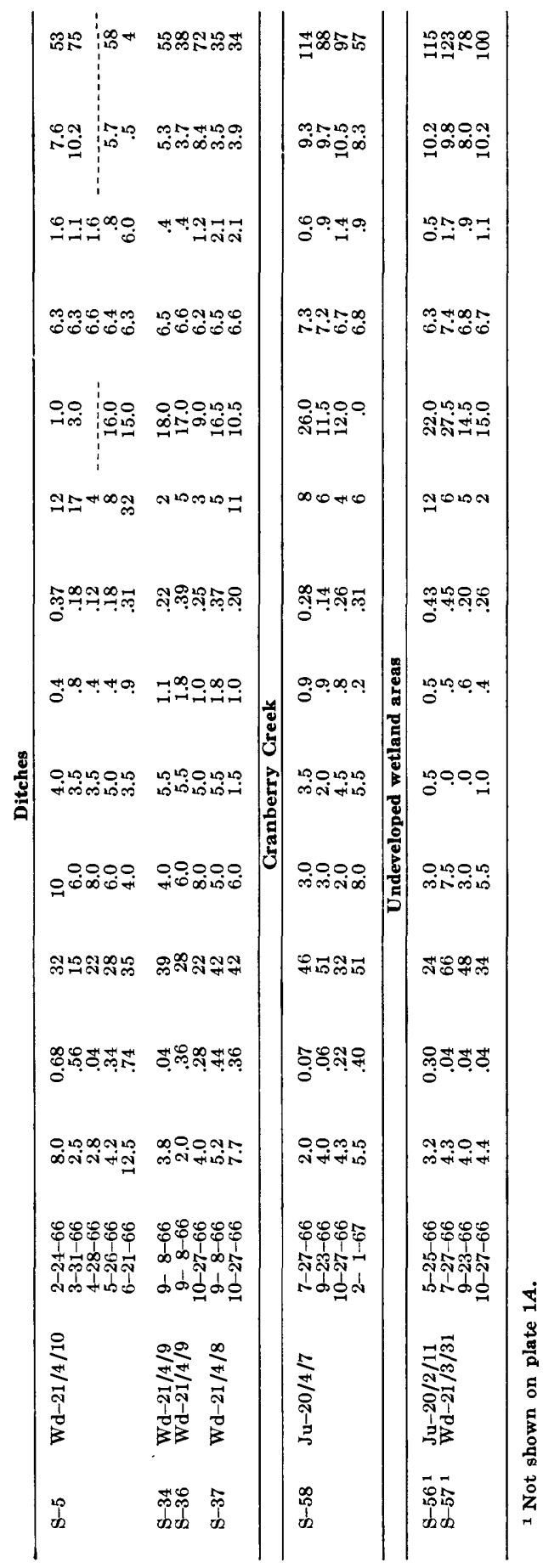




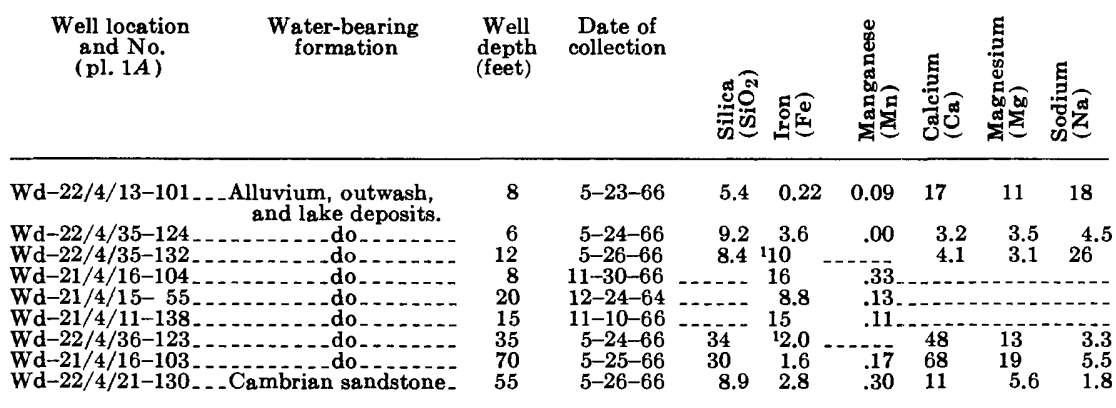

1 Field test.

concentrations of colloidal organic material impart a dark-gray color to the water. Representative partial chemical analyses of water from various environments are tabulated in table 3 , and sites are shown on plate $1 A$.

Seasonal variations in chemical quality are most pronounced in reservoirs. Analyses of water for reservoir sampling sites S-1 and S-10 show seasonal variations typical of other reservoirs in the area.

In reservoirs, iron and manganese concentrations are high in winter, decrease in spring, and then gradually increase during late spring and summer (table 3). The dissolved iron and manganese contents in water depend on DO (dissolved oxygen) concentrations because oxidation of the ions causes them to precipitate. Low DO concentrations in ice-covered reservoirs in winter allow high concentrations of iron and manganese to remain in solution. After the ice melts, oxygen is added to the water, causing iron and manganese to precipitate. Also, rain and snowmelt in spring dilute iron and manganese concentrations. In summer, concentrations of iron and manganese gradually increase as DO decreases.

Quality of Wisconsin River water is similar to that of water in the bogs. However, diverted water has a slightly higher sulfate content. The reservoir sampled at site S-10 (table 3) is the first to receive water from the Wisconsin River. Water diverted from the river does not apper to have deleterious effects $c \eta$ cranberry culture (Malcolm N. Dana, oral commun., 1969).

Water from flooded bogs is chemically similar to water in the reservoirs, except for high phosphorus concentrations in water in 
location number gives, in order, county (Wood, Wd), township, range, section, and USGS number]

\begin{tabular}{|c|c|c|c|c|c|c|c|c|c|c|c|c|c|c|}
\hline \multirow[b]{2}{*}{ 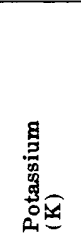 } & \multirow[b]{2}{*}{ 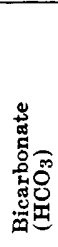 } & \multirow[b]{2}{*}{ 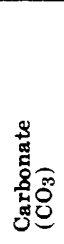 } & \multirow[b]{2}{*}{ 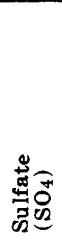 } & \multirow[b]{2}{*}{ 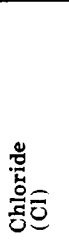 } & \multirow[b]{2}{*}{ 旁国 } & \multirow[b]{2}{*}{ 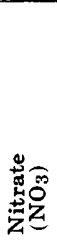 } & \multirow{2}{*}{ 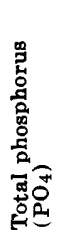 } & \multirow[b]{2}{*}{ 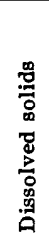 } & \multicolumn{2}{|c|}{$\begin{array}{l}\text { Hardness } \\
\left(\mathrm{CaCO}_{3}\right)\end{array}$} & \multirow[b]{2}{*}{ 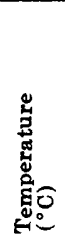 } & \multirow{2}{*}{ 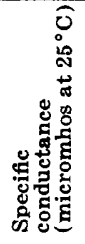 } & \multirow[b]{2}{*}{ 窇 } & \multirow{2}{*}{ 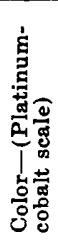 } \\
\hline & & & & & & & & & 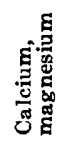 & 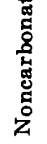 & & & & \\
\hline 3.1 & 52 & 0 & 34 & 31 & 0.1 & 14 & 0.05 & 196 & 88 & 45 & 9.0 & 287 & 6.6 & 5 \\
\hline $\begin{array}{l}1.1 \\
1.2 \\
1.1\end{array}$ & $\begin{array}{r}4 \\
36 \\
54 \\
30 \\
46 \\
212 \\
310 \\
46\end{array}$ & $\begin{array}{l}0 \\
0 \\
0 \\
0 \\
0 \\
0 \\
0 \\
0\end{array}$ & $\begin{array}{r}8.0 \\
17 \\
.8 \\
3.6 \\
8.8 \\
2.8 \\
1.2 \\
14\end{array}$ & $\begin{array}{c}14 \\
18 \\
6.0 \\
7.0 \\
1.0 \\
3.0 \\
1.0 \\
3.0\end{array}$ & $\begin{array}{l}.2 \\
.2 \\
.1\end{array}$ & $\begin{array}{l}2.9 \\
2.6 \\
4.8 . \\
2.1- \\
1.1- \\
1.0 \\
1.8 \\
.7\end{array}$ & $\begin{array}{l}.32 \\
.14 \\
.06\end{array}$ & $\begin{array}{r}52 \\
118 \\
86 \\
54 \\
71 \\
248 \\
319 \\
84\end{array}$ & $\begin{array}{r}22 \\
23 \\
48 \\
26 \\
37 \\
174 \\
248 \\
50\end{array}$ & $\begin{array}{r}20 \\
0 \\
4 \\
2 \\
0 \\
0 \\
0 \\
13\end{array}$ & $\begin{array}{r}7.0 \\
9.5 \\
12.0 \\
8.0 \\
10.0 \\
10.0 \\
10.0 \\
7.0\end{array}$ & $\begin{array}{r}75 \\
169 \\
120 \\
76 \\
94 \\
330 \\
470 \\
124\end{array}$ & $\begin{array}{l}6.1 \\
6.0 \\
6.5 \\
6.3 \\
6.2 \\
7.5 \\
6.7 \\
5.7\end{array}$ & $\begin{array}{r}400 \\
320 \\
230 \\
300 \\
150 \\
12 \\
22 \\
20\end{array}$ \\
\hline
\end{tabular}

the bogs (table 3 ). The high phosphorus concentrations prokably reflect the use of fertilizer for cranberry plants.

Water from ditches that drain bogs is also similar in quality to bog water but contains lower nitrate and phosphate concentrations.

Little difference exists between the quality of surface outflow from the study area and the quality of water in the undeveloped wetland area. (See S-57 and S-56, table 3.)

\section{GROUND-WATER QUALITY}

Ground water, which is similar in quality to surface water, is moderately hard, contains excessive iron and manganese, and is slightly acidic (table 4). Highest concentrations of most chemical constituents occur in alluvium underlying lake clay and silty sand.

Samples of water collected from shallow alluvium contrined 52 to $196 \mathrm{mg} / \mathrm{l}$ (milligrams per liter) of dissolved solids, 0.22 to $16 \mathrm{mg} / \mathrm{l}$ of iron, and 22 to $88 \mathrm{mg} / \mathrm{l}$ of hardness; they have a $\mathrm{pH}$ of 6.0 to 6.6. The water is generally yellowish brown and may contain some organic constituents.

\section{SUITABILITY OF WATER QUALITY FOR CRANBERRY CULTURE}

The $\mathrm{pH}$ and dissolved oxygen content of irrigation and flocding water in the Cranmoor area generally are adequate for cranberry culture; however, more acidic water would be desirable for the plants. 
Flooding water used for cranberry culture in Wisccnsin is more alkaline and has a higher $\mathrm{pH}$ than water used for the same purpose in other States (Franklin and Stevens, 1946). The $\mathrm{pH}$ of water used in cranberry bogs in the Cranmoor area is generally between 5.7 and 6.7. Use of water with a $\mathrm{pH}$ greater than 7.0 probably has a deleterious effect on cranberry plants (Franklin and Stevens, 1946.) When $\mathrm{pH}$ exceeds 6.5 , excessive weed growth reduces cranberry production. When $\mathrm{pH}$ is lower than 5.0 , cranberry vines have difficulty assimilating soil nutrients (Malcolm N. Dara, oral commun., 1969).

Dissolved oxygen in Cranmoor water is generally between 4 and $10 \mathrm{mg} / \mathrm{l}$ during the growing season and may decrease to zero in the winter. If the dissolved oxygen content of the water is less than $4 \mathrm{mg} / \mathrm{l}$, growth and blossoming of cranberry plants may be retarded. Plants are least vulnerable to low dissolved oxygen in the winter, when they are dormant and encased in ice.

The chemical quality of ground water in shallow clluvium and in sandstone is suitable for cranberry culture. Water in deep alluvium may be less suitable than water in shallow alluvium because of lower acidity; one sample had a pH of 7.5.

\section{WATER AVAILABILITY}

Surface water is and will continue to be the most readily available source of water for cranberry culture in the Crs nmoor area. However, ground water is available for supplemental supply in the central, southern, and eastern parts of the area. Addit: onal surface water can be made available by increasing reservoir volume and diverting water from outside the basin.

Ground water in sufficient quantities for cranberry sprinkling and irrigating is available from tubular wells in alluvium in the central, southern, and eastern parts of the basin, where sand and gravel is more than 50 feet thick (pl. 2). The thickest known deposits, in sec. 34 , T. 22 N., R. 4 E., and in sec. 20 , T. 21 N., R. 5 E., might yield 500 to $1,000 \mathrm{gpm}$ to properly constructed wells. Southeast of the study area, similar yields can be ol tained from deposits that exceed 50 feet in saturated thickness. O'ly about 20 percent of the existing cranberry bog area, mostly near Cranmoor, has ground-water supplies adequate for sprinkler systems.

The availability of ground water southeast of the existing cranberry bogs suggests future expansion in these areas. Northward expansion may be restricted by thin alluvium and lov availability of ground water. 
Saturated deposits less than 50 feet thick, which cover most of the northern and western parts of the area, generally yield less than $50 \mathrm{gpm}$ to wells. In these areas much more ground water may be withdrawn by pumping from pits, collectors, and deerened ditches.

Wherever wells are constructed in the thicker sand and gavel deposits near streams, flooded ditches, or reservoir marshes, high well yields $(1,000 \mathrm{gpm})$ can be expected. The extremely high well yields at Nekoosa result from a combination of a highly permoable aquifer and recharge from Moccasin Creek.

Sandstone is moderately permeable and may yield as much as $200 \mathrm{gpm}$ in the western part of the study area, where it is as much as 60 feet thick. Little or no ground water can be obtained from crystalline rocks because they are dense and porly permeable.

\section{CONCLUSIONS}

Surface water is available for current cranberry culture and is generally adequate in quantity and suitable in quality. However, major expansion of cranberry acreage will require additional water. These water supplies can be obtained by increasing civersion of surface water, expanding storage in reservoirs, and 'ioveloping local sources of ground water.

Surface water, the present supply for all cranberry culture, is derived predominantly from ditches and reservoirs in wet'ands within Cranberry Creek basin. Additional water is diverted into the area from the Wisconsin River in the east and from Hemlock Creek in the west.

Ground water of satisfactory quantity and quality is available in the central, eastern, and southern parts of the basin to fulfill future needs for sprinkling, frost protection, and irrigation of cranberry crops. Additional ground water could be brought to the bogs by ditches from southeastern areas of thick sand deposits. Supplemental water in the northern part of the area, in rlaces where alluvium averages about 20 feet in thickness, could be doveloped for cranberry culture by pumping from pits, shallow collectors, and ditches. Yields of less than $50 \mathrm{gpm}$, for purposes such as domestic use, could be developed from tubular wells.

Deposits of saturated sand, which exceed 50 feet in thickness in much of the central and southern parts of the area, should yield 500 to $1,000 \mathrm{gpm}$ to properly constructed wells. In the western part of the area, where sandstone is as much as 60 feet thick, wells may yield as much as $200 \mathrm{gpm}$. 
The chemical quality of ground water in shallow s.lluvium and sandstone is suitable for cranberry culture. Water in deep alluvium in the buried channel near Cranmoor has a pH as high as 7.5, which may not be satisfactory for cranberry culture.

The quality of surface water in the wetlands is suitable for cranberry culture. It is soft, has a pH generally betreen 5.7 and 6.7, and generally has adequate DO; however, the water does contain colloidal material. Water diverted from the Wisconsin River is similar in quality to surface water in the Cranberry Creek basin but contains more sulfate. Wisconsin River water has not had deleterious effects on cranberries.

The quality of water in reservoirs and flooded bogs varies seasonally because of dilution from snowmelt and rainfall, diversions from outside the basin, and winter reduction of $\mathrm{DO}$. Water in flooded bogs is chemically similar to water in the reservoirs except that it has higher phosphorus concentrations. Little difference exists between the quality of surface outflcw from the cranberry bogs and the quality of water in adjacent, undeveloped wetland areas.

The hydrologic system operating in the wetlands is relatively simple but is altered by diversions, drainage thro'igh ditches, storage in reservoirs, and sprinkling of bogs. Diversion of water into the basin increases annual runoff, but, because the water is temporarily held in reservoirs, it does not contribute significantly to low flow. During the filling of reservoirs the streamflow of Cranberry Creek decreases. Subsequent drainage of bogs temporarily increases the streamflow.

Ground water and surface water are closely related in the basin, and ground water contributes nearly all the flow to streams and reservoirs except for diversions and periodic floods. Ground-water movement through the basin generally parallels the north-to-south movement of surface water. Local movement of ground water is toward streams and ditches.

\section{REFERENCES}

Dana, M. N., and Klingbeil, G. C., 1966, Cranberry growing in Wisconsin: Wisconsin Univ., University Extension, Coll. Agriculture Circ. 654, 39 p.

Franklin, H. J., and Stevens, N. E., 1946, Weather and water as factors in cranberry production: Massachusetts Agriculture Expt. Sta. Bull. 433, $51 \mathrm{p}$.

Jones, G. O., McVean, N. S., and others, compilers, 1923, Hi tory of Wood County, Wisconsin: Minneapolis, Minn., H. C. Cooper, Jr., and Co., 795 p.

Wisconsin Department of Agriculture, 1961, Wisconsin climatological data: Madison, Wisconsin, Crop Reporting Service. 


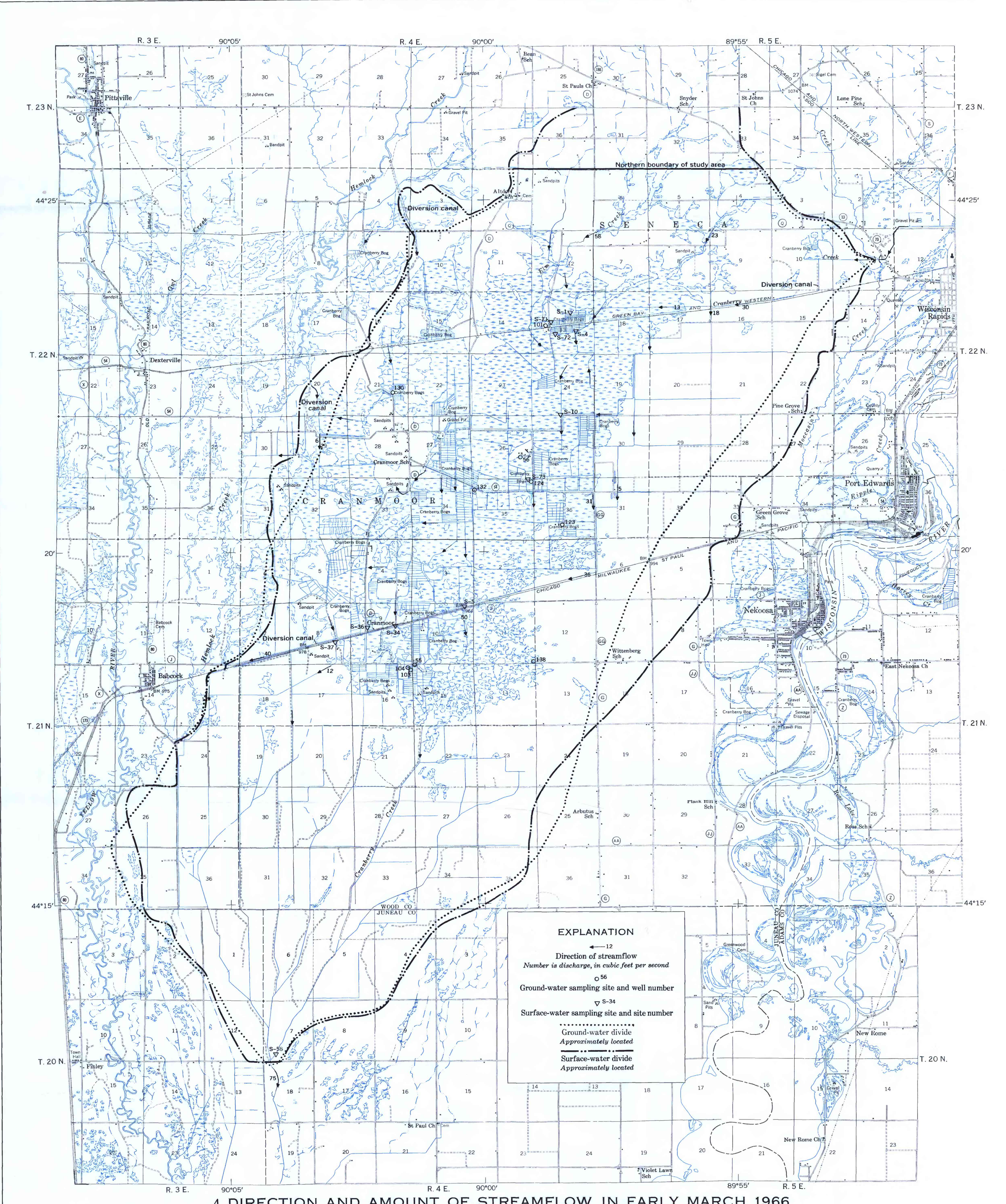

A. DIRECTION AND AMOUNT OF STREAMFLOW IN EARLY MARCH 1966

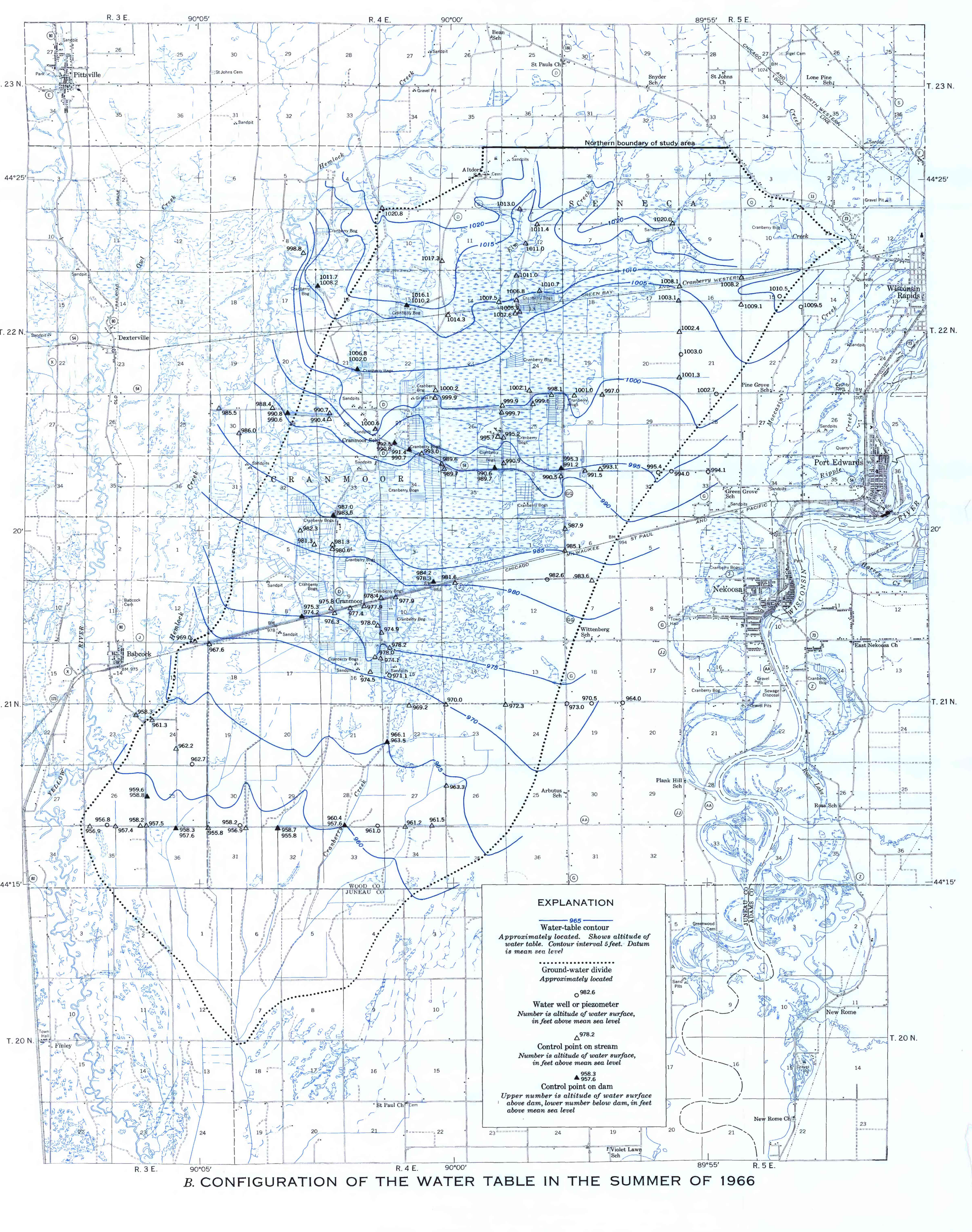



GEOLOGICAL SURVEY

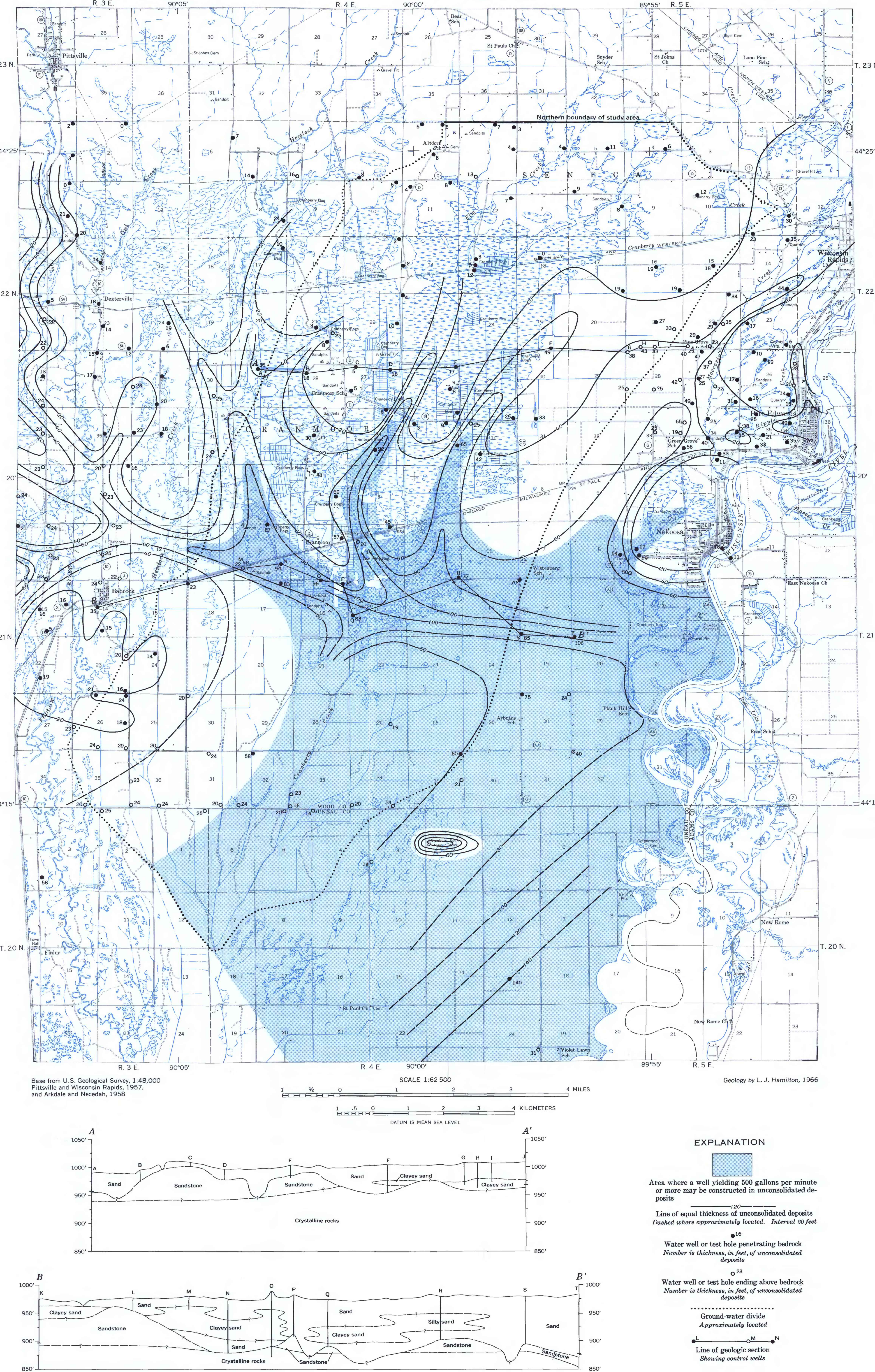

